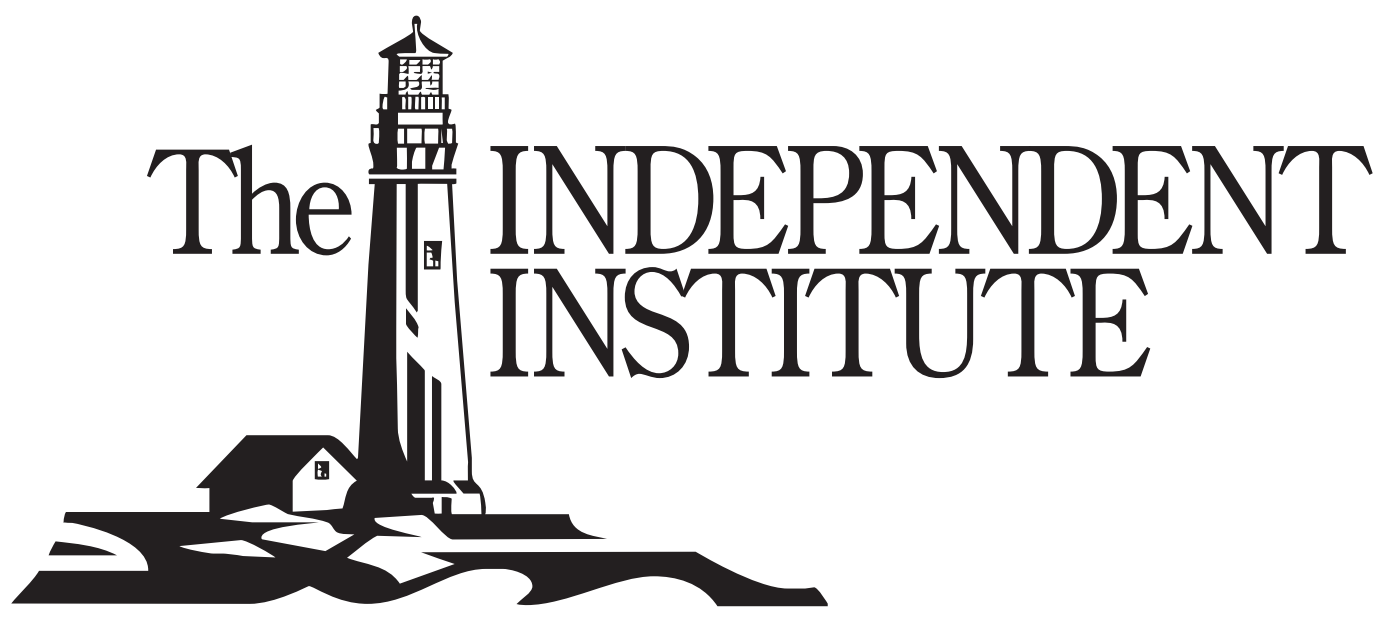

$\underline{\text { The Logic of Collective Belief }}$

Independent Institute Working Paper \#4

Bryan Caplan

October 1999 


\title{
The Logic of Collective Belief
}

\author{
Bryan Caplan \\ Department of Economics \\ and Center for the Study of Public Choice \\ George Mason University \\ Fairfax, VA 22030 \\ bcaplan@gmu.edu] \\ 703-993-2324
}

April, 1999

JEL Classifications: D72, D62, D84

Keywords: irrationality, collective choice, political failure

\begin{abstract}
:
Many political failure arguments implicitly assume that voters are irrational. (Wittman 1995, 1989; Coate and Morris 1995) This paper argues that this assumption is both theoretically and empirically plausible: In politics, rationality, like information, is a collective good that individuals have little incentive to supply. In consequence, voters are frequently not only rationally ignorant but also "rationally irrational." Rational irrationality leads to both demand side and supply side political failures: Competition not only pressures politicians to act on voters' biased estimates, but selects for politicians who genuinely share those biases. The analytical framework also sheds new light on log-rolling, political shirking and advertising, and politicians' human capital.
\end{abstract}

For discussion and useful suggestions I would like to thank Don Boudreaux, Tyler Cowen, Pete Boettke, Jim Schneider, Geoffrey Brennan, Bill Dougan, Bill Dickens, Mitch Mitchell, Ed Lopez, J.C. Bradbury, Todd Zywicki, David Bernstein, Robin Hanson, Dan Klein, Alex Tabarrok, Nicky Tynan, Timur Kuran, Ron Heiner, seminar participants at George Mason, participants at the Public Choice Outreach seminar and the Public Choice Society meetings, and members of my Armchair Economists' listserv. Gisele Silva provided excellent research assistance. The standard disclaimer applies. 
The trouble with people is not that they don't know but that they know so much that ain't so.

\section{Introduction}

Josh Billings, in Caruth and Ehrlich (1988, p.205)

Theories of political failure have been criticized for assuming that voters are irrational. 1 (Coate and Morris 1995; Wittman 1995, 1989; Austen-Smith 1991; Stigler 1986; Becker 1976) Few explicitly appeal to voter irrationality, but as Coate and Morris (1995) observe, "It is by no means clear that the Virginia view [that inefficient transfer programs exist] can be justified without making such unreasonable assumptions." ${ }^{2}$ (p.1212) Systematically biased beliefs about policy might cause political failure, but imperfect information will not bias the beliefs of rational voters; it merely increases their estimates' variance..$^{3}$ Similarly, exogenous imperfections like monopolistic elections or high transactions costs can imply political failure; but if political "industry structure" is itself an endogenous product of collective choice, it is unclear how inefficient institutions win rational voters' support in the first place.

This paper argues that the critics of political failure are incorrect to dismiss the possibility of voter irrationality as "unreasonable." It presents a model of "rational irrationality" in which economic agents have preferences over beliefs as well as outcomes, so irrationality increases as its private cost decreases. (Akerlof and Dickens 1982; Caplan 1999a) In a "Downsian" environment where the cost of erroneous beliefs is negligible,

\footnotetext{
${ }^{1}$ For these critics, and in the terminology of this paper, to be "rational" is to have rational expectations, and to be "irrational" is to fail to have rational expectations. (Sheffrin 1996; Pesaran 1987) By definition, fully rational agents may make mistakes, but not systematic ones.

${ }^{2}$ For some other recent responses to this line of criticism, see Rowley (1997), Boudreaux (1996), and Lott (1997a, 1997b).

3 "[T]o be uninformed about the nature of pork-barrel projects in other congressional districts does not mean that voters tend to underestimate the effects of pork barrel - it is quite possible that the uninformed exaggerate both the extent and the negative consequences of pork-barrel projects." (Wittman 1995, pp.15-16)
} 
the standard arguments for rational expectations (Sheffrin 1996; Pesaran 1987) have little force. The incentive structure that makes the variance of beliefs large ipso facto tends to bring out voters' irrational biases. As a corollary, voter rationality - like voter information - will normally be an under-produced collective good. (Olson 1982, 1965) Individual voters can cheaply indulge their systematically biased beliefs at the ballot box, knowing that they are extraordinarily unlikely to alter the outcome. (Akerlof 1989)

The paper proceeds to analyze how rational irrationality influences both the demand and supply sides of the political process. The main finding is that rational irrationality leads even voters with identical preferences and endowments to vote in favor of inefficient policies. Whether voters' beliefs are rational or irrational, electoral competition pressures politicians to do what voters want. Indeed, as Fremling and Lott (1996) suggest, winning politicians will probably genuinely share then confusions of their constituents. It is costly for politicians to have biased estimates of voters' reactions to their decisions, but cheap to have biased estimates of policies' actual effects.

The next section examines the model of rational irrationality, applies it to political beliefs, provides supporting empirical evidence, and critiques two similar views of voter behavior. Section three analyzes the mechanisms connecting rational irrationality to demand- and supply-side political failures. Section four concludes the paper.

\section{Rational Irrationality and Political Beliefs}

\section{a. Theory}

None of the standard arguments for rational expectations work for citizens in Downsian environments where the probability a vote will be decisive is essentially zero. (Downs 1957; Olson 1965) When it is cheap to estimate with a large variance, systematically 


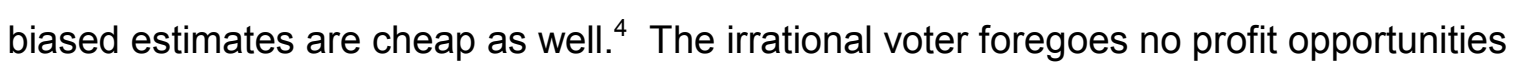
because the same platform wins no matter how biased one person's estimates are. As a corollary, arbitrage cannot make the electorate act "as if" everyone had rational expectations. (Muth 1961, p.330) There is no place for arbitrage when the rational get the same payoff as the irrational in any event. Models with learning often converge to rational expectations equilibria (Pesaran 1987, pp.32-48; Cyert and DeGroot 1974), but if there is no associated private benefit of rationality, there is no incentive to exert effort to learn.

On topics where these standard arguments for rational expectations fail, there is no reason for economists to rule out irrationality in advance. Caplan (1999a) develops a model of "rational irrationality" and argues that it explains why irrationality is particularly pronounced in politics, religion, and some other areas. Rational irrationality is an economic theory of agents' equilibrium departure from full rationality - and the magnitude of the associated systematic biases. Models of belief formation standardly assume that agents optimize along only one margin: the quantity of information acquired. Incurring more information costs reduces estimates' variance; the greater the costs of error, the more information one chooses to buy. The rational irrationality model focuses attention on a second margin: the degree of rationality with which one processes one's information. More rationality reduces estimates' systematic bias; the greater the costs of error, the more rational one chooses to be. (Diagram 1)

The theory of rational irrationality can be derived from two crucial assumptions. ${ }^{\text {D }}$ The

\footnotetext{
${ }^{4}$ See Caplan (1999a) for more detailed analysis.

${ }^{5}$ Caplan (1999a) provides a more fundamental derivation of the theory from indifference curves and budget constraints.
} 
first is that agents always have rational expectations about the price of irrationality. This is what differentiates rational irrationality from full-blown irrationality: On some level, people form unbiased estimates of the repercussions of self-deception. The second assumption is simply that demand for irrationality is downward-sloping. To maximize your material wealth you need rational expectations ${ }^{\text {[ }}$, but you may be willing to forego some wealth in order to retain cherished - though irrational - beliefs. The specific quantity of wealth one foregoes for a given belief in given circumstances is an exogenous function of technology. Assuming for convenience that costs are proportional to the degree of bias, the price of irrationality may be drawn as a horizontal line. The optimal quantity of irrationality (degree of systematic bias) is at the intersection of the agent's demand curve and the exogenously fixed price of irrationality. (Diagram 2)

By definition, a person who consumes zero irrationality has rational expectations. The irrationality demand curves of standard neoclassical agents with no preferences over beliefs are therefore vertical at $q=0$; these are termed "neoclassical" preferences. While I leave open the possibility that real individuals seriously deviate from neoclassical preferences (Caplan 1999b), the conclusions of this paper rely only upon the relatively weak assumption that agents have "near-neoclassical" preferences and associated demand-for-irrationality functions. (Diagram 3) Near-neoclassical agents buy zero irrationality when the price of irrationality is significant, but as the price approaches zero their consumption of irrationality sharply increases. Most of the time, the nearneoclassical have rational expectations, but when error costs become trivial, they give in

\footnotetext{
${ }^{6}$ There are exceptions to this rule; in particular, if there is extreme social pressure to be irrational on an issue, the price of irrationality could actually be negative. Such exceptional cases actually tend to strengthen this paper's finding that irrationality will be unusually pronounced in politics: With social pressure, a minority of "true believers" may induce a larger group of people to adopt an irrational belief they had no intrinsic inclination to accept. For a more detailed discussion of wealth-enhancing irrationality, see Caplan (1999b, 1999c).
} 
to their irrational side.

A key feature of beliefs is that some have practical consequences for the individual adherent, while others do not. For example, the belief that protectionism is a wealthenhancing national policy makes little difference for the individual adherent, who still enjoys the benefits of international trade. But holding that household self-sufficiency is the path to prosperity has large private costs. Diagram 4 shows the contrast. People restrain their consumption of irrationality when it is costly; but if its price is zero they consume irrationality until they are "satiated. ${ }^{7}$ In elections or surveys, for example, agents with near-neoclassical preferences have plainly irrational views, even though those with neoclassical preferences remain fully rational.

Rational irrationality should not be seen as an extreme case of rational ignorance. Both tend to arise in Downsian environments, but the problems are conceptually distinct and have different aggregate consequences. Intuitively, a person with ample free information might still choose to irrationally disregard it; conversely, a person with virtually no information could still take full advantage of the little that he does know. The distinction between ignorance and irrationality is important because - as critics of political failure arguments point out - rational political actors have workable methods for coping with ignorance. Voters do not normally have to personally bear the costs of informing themselves; the media, politicians, and interest groups have an incentive to supply

\footnotetext{
${ }^{7}$ Frequently, irrational beliefs will also be held dogmatically, i.e., with excessive certainty relative to the information possessed. This can be modeled as a choice to have a systematically biased estimate of the variance of a belief. (Caplan 1999a) In general, one would expect bias about an issue and systematic underestimates of variance to appear together: it would be strange to hold a systematically biased view with a healthy dose of skepticism. Moreover, the private marginal costs of these two kinds of errors are likely to be highly correlated: If the cost of bias about an issue is zero, then holding one's view on the issue with certitude or near-certitude is also likely to be costless.
} 
information for free. (Wittman 1995; Popkin 1991) If politicians or special interests disseminate biased information, rational voters will discount it in favor of more objective sources. If there are asymmetric information problems, rational voters respond by buying less government. The programs they support in spite of imperfect information will therefore be (on average) a net benefit; only the programs that credibly signal their merit will win approval. (Breton and Wintrobe 1982; Wintrobe 1987; Austen-Smith 1991) If it is costly to monitor politicians, rational voters can compensate with a punishment multiplier. (Becker 1968; Bender and Lott 1996)

The rationally irrational agent, in contrast, discounts information that contradicts - and over-weights information that supports - his desired beliefs. It makes no difference whether the agent incurs the information costs or someone else pays for him. This makes it much more difficult to compensate for irrationality than for ignorance. The rationally irrational agent acts as if his biased beliefs were actually known to be true. A person with irrationally favorable estimates of the benefits of protectionism, for example, could easily maintain that he already has all of the information about international trade he needs. If one branch of the media tries to correct him, he tunes it out in favor of competing media that tell him what he wants to hear. Similarly, irrational voters may enthusiastically support programs of unknown quality, denying that an asymmetric information problem even exists. In other words, the rationally ignorant at least acknowledge that they have a problem, so they are open to compensatory political measures. Politicians who support such measures win the voters' favor. The rationally irrational, however, deny that they have a problem; they don't want the political system to "help them" overcome their irrational biases. In their eyes, such compensatory political measures are useless at best, and insulting at worst. Politicians who support them have little to gain and much to lose. 


\section{b. Evidence}

For an overwhelming majority of people, political beliefs are costless. Elections and public opinion have a clear impact on policy, but the odds are near zero that one vote will change an election's result, or one respondent will change measured public opinion. In politics, irrationality is close to free. The theory of rational irrationality thus predicts an unusually high level of irrationality in politics. Space constraints make a comprehensive examination of political irrationality impossible. The following instead focuses on one cluster of irrational beliefs: so-called "populist" attitudes and the systematically mistaken descriptive beliefs about economics and the economy that underlie them.

"Populist" attitudes jointly blame foreigners, welfare recipients, and business for most national problems, and prescribe some unorthodox solutions. Even though economists across the political spectrum tend to oppose populist economic policies as ineffective or counter-productive, they have substantial public support. (Saad 1996) Opposition to policies perceived to benefit foreigners is particularly pronounced: Only $6.3 \%$ of respondents to the General Social Survey (1996; henceforth GSS) favor increasing immigration by any amount, and fully $65.4 \%$ favor decreasing it; similarly, $74.2 \%$ hold that too much is spent on foreign aid. ${ }^{8}$ Welfare programs enjoy slightly more support, but according to the National Survey of Public Knowledge of Welfare Reform and the Federal Budget (1995), a majority of both political parties agree that welfare spending is excessive:

\footnotetext{
${ }^{8}$ Author's tabulation of the General Social Survey (1996). Variable identifiers LETIN and
} NATAID. 
Table 1: Americans' Views About U.S. Spending On Welfare

\begin{tabular}{|l|l|l|l|}
\hline Political Party Affiliation & Total & Democrat & Republican \\
\hline Spend Too Much & 64 & 57 & 78 \\
\hline Spend Too Little & 12 & 14 & 5 \\
\hline Spend About the Right Amount & 17 & 26 & 9 \\
\hline Don't Know & 7 & 3 & 8 \\
\hline Source: National Survey of Public Knowledge of Welfare Reform and the Federal Budget, Question 5 \\
\hline
\end{tabular}

Policies to regulate business and increase the number of jobs are likewise quite popular considering economic analysis of their effects. Data from the GSS indicate that solid majorities strictly favor relatively moderate populist efforts such as "make work" programs and support for declining industries. (Table 2) For two drastic populist measures - price controls and "share the work" policies - the median respondent is indifferent (although opponents do outnumber proponents).

Table 2: Support for Populist Economic Policies

\begin{tabular}{|l|l|l|l|l|l|}
\hline $\begin{array}{l}\text { Prompt: "Here are some things } \\
\text { the government might do for the } \\
\text { economy." }\end{array}$ & $\begin{array}{l}\text { Strongly } \\
\text { in Favor }\end{array}$ & In Favor & Neither & Against & $\begin{array}{l}\text { Strongly } \\
\text { Against }\end{array}$ \\
\hline $\begin{array}{l}\text { "Government financing of } \\
\text { projects to create new jobs." }\end{array}$ & 25.8 & 43.7 & 19.0 & 9.0 & 2.5 \\
\hline $\begin{array}{l}\text { "Supporting declining industries } \\
\text { to protect jobs." }\end{array}$ & 15.9 & 35.7 & 26.3 & 17.9 & 4.2 \\
\hline "Control of prices by legislation." & 9.0 & 27.7 & 23.9 & 27.6 & 11.8 \\
\hline $\begin{array}{l}\text { "Reducing the work week to } \\
\text { create more jobs." }\end{array}$ & 7.4 & 17.7 & 31.9 & 31.5 & 11.5 \\
\hline \multicolumn{2}{|l|}{ Source: GSS. Variable identifiers: MAKEJOBS, SAVEJOBS, SETPRICE, CUTHOURS } \\
\hline
\end{tabular}

It is conceivable that populism is a pure preference, but in practice it is closely linked to systematically mistaken factual claims. The public seriously overestimates the fraction of the federal budget spent on welfare and foreign aid. When the National Survey of Public Knowledge of Welfare Reform and the Federal Budget (1995, Table 16) asked the public to name the two "largest areas of government spending" from a list of six areas (foreign aid, welfare, interest on the federal debt, defense, Social Security, and health), only $37 \%$ and $14 \%$ respectively correctly named defense and Social Security. 
"Foreign aid" was the most frequently cited: $41 \%$ thought that it was one of the two largest areas of federal spending, even though in reality it is less than $1 \%$ of the federal budget. "Welfare" came in second: $40 \%$ ranked it as one of the two largest federal programs. ${ }^{9}$ With estimates this biased, the unpopularity of foreign aid and welfare is easy to understand.

Similarly, on average, the public underestimates the applicability of textbook supply-anddemand analysis of adverse shocks. The Survey of Americans and Economists on the Economy (1996, Question 26) asked "Which do you think is more responsible for the recent increase in gasoline prices: the normal law of supply and demand, or oil companies are trying to increase profits?" Only $22 \%$ of the general public accepted the supply-and-demand explanation, compared to $85 \%$ of economists, while $73 \%$ and $8 \%$ respectively affirmed the second explanation. Such reactions seem to be typical: see Fremling and Lott's $(1996,1989)$ discussion of public opinion and the 1970's oil shocks.

The Survey of Americans and Economists on the Economy's (1996) battery of questions asking the general public and professional economists to assess various explanations for "why the economy is not doing better than it is" provides further evidence that populism rests on systematically erroneous descriptive views. On questions about welfare, foreigners, and business, the public's estimates and economists' could hardly be more different (Table 3).

\footnotetext{
${ }^{9}$ Because the term "welfare" is somewhat open to interpretation, the same study also gave respondents a list of programs (the choices: "food stamps," "AFDC, or Aid to Families With Dependent Children," "public housing," "WIC, or the Women, Infants, and Children program," "the school lunch program," "Medicaid," "SSI, or Supplemental Security Income," "Medicare," and "Social Security") and asked them to indicate which they considered to be "welfare." A majority of respondents counted food stamps, AFDC, public housing, WIC, school lunches, and Medicaid as welfare. These six programs comprised $10.2 \%$ of the 1993 federal budget. (National Survey of Public Knowledge of Welfare Reform and the Federal Budget 1995, Table 15)
} 
Table 3: The Public and Economists on "Why the Economy is not Doing Better Than It Is"

\begin{tabular}{|l|l|l|l|l|}
\hline \multicolumn{5}{|c|}{ General Public } \\
\hline & $\begin{array}{l}\text { Major } \\
\text { Reason }\end{array}$ & $\begin{array}{l}\text { Minor } \\
\text { Reason }\end{array}$ & $\begin{array}{l}\text { Not a } \\
\text { Reason }\end{array}$ & $\begin{array}{l}\text { No } \\
\text { Opinion }\end{array}$ \\
\hline Too many people are on welfare. & $70^{*}$ & 22 & 7 & 1 \\
\hline Foreign aid spending is too high. & $66^{*}$ & 23 & 10 & 1 \\
\hline There are too many immigrants. & 47 & $32^{*}$ & 19 & 1 \\
\hline Companies are sending jobs overseas. & $68^{*}$ & 25 & 6 & 1 \\
\hline Business profits are too high. & 46 & $36^{*}$ & 17 & 1 \\
\hline Technology is displacing workers. & 46 & $38^{*}$ & 15 & 1 \\
\hline Companies are downsizing. & $59^{*}$ & 30 & 9 & 2 \\
\hline \multicolumn{7}{|c}{ Economists } \\
\hline Explanation & Major & Minor & Not a & No \\
& Reason & Reason & Reason & Opinion \\
\hline Too many people are on welfare. & 11 & $50^{*}$ & 39 & 0 \\
\hline Foreign aid spending is too high. & 1 & 13 & $86^{*}$ & 0 \\
\hline There are too many immigrants. & 1 & 19 & $80^{*}$ & $<.5$ \\
\hline Companies are sending jobs overseas. & 6 & 35 & $58^{*}$ & $<.5$ \\
\hline Business profits are too high. & 4 & 11 & $85^{*}$ & 1 \\
\hline Technology is displacing workers. & 2 & 24 & $74^{*}$ & $<.5$ \\
\hline Companies are downsizing. & 5 & 38 & $57^{*}$ & 0 \\
\hline Source: Survey of Americans and Economists on the Economy, Questions 27 and 29 & ${ }^{*}=$ median belief \\
\hline
\end{tabular}

If the disparity were due to information costs, one would expect the relatively uninformed opinions of the public to be widely but approximately evenly dispersed around economists' mean estimates. Instead, the general public tends to see "major problems" that informed observers doubt are problems at all. The divergence is smallest on welfare: A majority of both groups does agree that "too many people on welfare" is a problem. The general public, however, overwhelmingly sees it as a "major reason why the economy is not doing better than it is" while only $11 \%$ of economists concur. On the remaining questions about foreigners and business, the divide is still greater. In each of the six cases, the plurality of the public sees a "major reason" for the economy's shortcomings, while a majority of economists deny that the proffered explanation matters at all.

Given a taste - however limited - for populist beliefs, it is easy to explain why many embrace extreme populist conclusions: Relative prices matter. It is all but impossible for 
one voter's populism to actually make policy more populist, so from the point of view of the individual, political populism is a free good. Such mistakes are much more costly in market settings. If you irrationally judge that immigrants cannot competently run convenience markets, you will probably have to pay higher prices or more shopping time to avoid this phantom threat. No comparable private cost attaches to voters with the irrational belief that immigrants threaten the survival of the nation.

\section{c. Alternative Explanations}

The theory of rational irrationality partially resembles two other recent approaches to voter behavior: Fremling and Lott's $(1996,1989)$ theory of the "bias towards zero in aggregate perceptions" and Brennan and Lomasky's (1993, 1989) expressive voting theory. All three theories conclude that voters will sometimes favor counter-productive policies. All three emphasize that there is an underlying economic logic behind apparently irrational voter choices. But contrary to this paper's thesis, both Fremling and Lott and Brennan and Lomasky basically retain the view that individual voters are rational. As a result, there are important features of voter behavior that rational irrationality can readily explain that these alternatives cannot.

The Bias Toward Zero in Aggregate Perceptions. Fremling and Lott $(1996,1989)$ try to allow for systematic voter bias without abandoning rational expectations. To conserve mental resources, they argue, voters implicitly estimate only a handful of the enormous number of logically possible econometric models of the economy. Their estimates are unbiased if their model is correct, but if they misspecify the model by omitting variables, that sets their implicit coefficient estimate for those variables to zero. At the aggregate level, then, if some people include a critical variable while others exclude it, the average perception will be biased towards zero. 
While Fremling and Lott's point is novel, it seems like an easy problem for rational voters to surmount. The experts can drastically lighten the public's estimation work by whittling the number of competing hypotheses down to a manageable handful. Even if the experts are one-sided, voters can still readily extract the information they need: Ex hypothesi, voters can estimate a model without bias so long as the media or politicians mention the possibility that a given model is correct. At least in Fremling and Lott's model, "All publicity is good publicity." This makes it difficult for Fremling and Lott's theory to explain some of the most prominent of the public's biases. Populists, for example, frequently deride economists' views, which at least indicates they are aware of the existence of alternative hypotheses. And in many cases, economists and the public seem to agree on the variables that belong in the econometric model but disagree about the sign of the coefficients. Both groups affirm, for example, that per-capita welfare is a function of the degree of protectionism. But the public is much more likely to think that the sign is positive than economists are.

Expressive Voting. Brennan and Lomasky $(1993,1989)$ argue that because a voter's choice is almost never decisive, "expressive," not "instrumental" values determine how (not just whether) people vote. Moreover, instrumental and expressive values are sometimes negatively correlated: peace may be a much better outcome than war, but national pride has more expressive value than compromise. The political dominance of expressive values can lead to what Brennan and Lomasky call "the voters' dilemma": if everyone indulges their expressive tastes, ignoring the actual consequences of policies, then emotionally appealing but suboptimal policies will win out.

The theory of expressive voting challenges the collective rationality of democratic 
decision-making on a deep level, without raising doubts about voters' individual rationality. A person can have rational expectations about the effects of different policies, but still vote for those with the catchiest slogans. Still, how much expressive value can voting for counter-productive policies have? In most cases, the expressive value of policies would fade if they were widely seen as ineffective: if people had rational expectations about the consequences of gas price controls, would it still be inspiring to vote for them? Would they vote (or enthusiastically cheer) for war fully believing they will lose? In other words, instrumental beliefs frequently underlie expressive preferences. If these instrumental beliefs were rational, then the collectively irrational effects of expressive voting would probably be mild.

\section{How Rational Irrationality Causes Political Failure}

Markets may function "as if" everyone had rational expectations even if most people do not. (Camerer 1987) Does the same apply to politics? This section shows that when standard models of competitive democracy aggregate the preferences of rationally irrational voters, outcomes have no particular tendency to be more rational than the voters themselves. (Frey and Eichenberger 1991) As discussed at the close of section $2 a$, it is much easier for institutions to compensate for voter's rational ignorance than for their rational irrationality. The rationally ignorant at least admit that they are uninformed, so when someone (the media, politicians, etc.) gives them additional information for free, they take full advantage of it. The rationally irrational see matters differently: they think they already know enough to ascertain the right answer. Giving them evidence that their judgments are mistaken is unlikely to change their minds. Even if unwanted information is provided free of charge, it is also freely disposable. 


\section{a. The Demand Side}

Suppose that voters with identical endowments and preferences participate in majoritarian competitive elections. It appears as if democratic elections would necessarily be efficient. Whichever politician had the platform closest to the electorate's shared most-preferred policy would get $100 \%$ of the votes; political competition forces the winner to implement the welfare-maximizing platform. (Becker 1958) But if these identical voters also have preferences over beliefs, this inference is invalid 10 Each voter maximizes his utility, but this does not maximize the utility of voters as a group.

To understand the mechanism, suppose that identical citizens share a near-neoclassical preference for overestimating the welfare-maximizing level of protection. When the price of bias is zero, they all want to believe that some level of harmful protectionist policies will actually make them better off. The higher their estimate of this welfare-maximizing level of protection, the more protection they want and are willing to vote for. Note that no individual can appreciably change the election's outcome, so as usual the private cost of irrationality is zero. At the margin then, each person chooses to irrationally overestimate the benefits of protection - and votes accordingly. Given identical voters and competitive elections, the Pareto-inferior protectionist platform wins unanimously. (Diagram 5)

When voters are identical along every dimension, any policy-relevant demand for irrationality at $\mathrm{P}=0$ therefore implies political failure. If one person holds a specific irrational belief, so does everyone else. People according vote for whatever policies they would most prefer were their beliefs correct, and competitive elections make those

\footnotetext{
${ }^{10}$ Brennan and Lomasky (1993) point out that it is also necessary to assume that citizens vote instrumentally rather than expressively. But as argued earlier, it is unlikely (though by no means impossible) that ineffective policies would have much expressive value if voters had rational expectations about their consequences.
} 
policies a reality. What about the utility of the irrational beliefs themselves? Doesn't this compensate for the disutility of worse policy? The answer is that with near-neoclassical preferences, the utility of irrational political beliefs can be safely ignored when assessing policies' efficiency. Since individuals' demand for irrationality falls to zero at a small positive price, the total surplus associated with the irrational beliefs is trivial. But more serious deviations from rationality moderate this result: Akerlof $(1989$, p.10) shows that efficient policies must discount - but not completely ignore - the utility that citizens derive from irrational political beliefs. The intuition Akerlof's piece shares with mine is that electoral outcomes are inefficient because they respond to preferences over beliefs "at par" even though the private and social costs of irrationality differ.

Allowing for heterogeneous near-neoclassical belief preferences while retaining the assumption that voters are identical in every other respect partially mitigates the inefficiency of irrationality. In this case, political failure does not automatically accompany irrationality, because one person's irrationality could conceivably "balance out" the irrationality of others. For instance, voters who irrationally overestimate the problems with "big government" tend to offset those who irrationally underestimate them.

Consider the distribution of beliefs about protection that a population of otherwise identical citizens will hold when the price of irrationality is zero. (Diagram 6) Since voters support different policies solely because they have different beliefs, the median voter and the median believer are the same person. If irrational free-traders and irrational protectionists are equally numerous, for example, the median belief remains unbiased. Winning policies then mimic those that would have arisen with a fully rational electorate; in both cases, the median voter has rational expectations and is decisive. Conversely, if the median belief is biased, then the winning policies reflect that bias. The magnitude of 
political failure is not determined by the level of irrationality; it is rather an increasing function of the degree to which the median belief strays from unbiasedness. (Diagram 6) Lop-sided bias is the key.

The connection of irrationality to political failure should not be downplayed on this ground. If irrationality is a taste rather than random measurement error, there is no a priori reason to expect it to balance out and leave the median belief unbiased. Public opinion often does exhibit strong lop-sided biases. (Table 3) Xenophobes vastly outnumber xenophiles. People who blame oil companies for shortages are overwhelmingly more numerous than people who blame price controls. People who underestimate the fraction of the budget spent on welfare are few compared to people who overestimate it. These sorts of mainstream biases drive political failure as the irrationality of a few extremists cannot. 12

Consider a population of otherwise identical voters with the same distribution of beliefs that the general public in fact exhibits, as shown in Table 3. Since they differ solely in their beliefs, citizens in this thought experiment vote differently only because they disagree about positive economics. The more harm they think foreign aid causes, for example, the less foreign aid they are willing to vote for. The $10 \%$ of the electorate that denies that foreign aid adversely affects economic performance will be more supportive

\footnotetext{
${ }^{11}$ If the mean and the median of the distribution of beliefs are equal, then political failure is an increasing function of the degree of deviation from "rational expectations in the aggregate." (Haltiwanger and Waldman 1989)

${ }^{12}$ Allowing for heterogeneous endowments and (non-belief) preferences complicates the welfare analysis, but the central intuition does not change. The clean connection between the magnitude of political failure and the median degree of bias however no longer necessarily holds, even supposing that the rational expectations median voter result would be optimal. The reason is that the type and magnitude of irrationality might interact with tastes, wealth, or other characteristics, so the "median believer" is not the median voter. Balanced irrationality can then have an imbalanced impact on the median voter's preference.
} 
of foreign aid than the $23 \%$ of the electorate that sees it as a "minor" problem; they in turn will favor more foreign aid than the $66 \%$ that view it as a "major reason" for subpar economic performance. A standard competitive election about foreign aid would have the predictable median-voter outcome. What is unusual about this election, however, is that the median voter and the median believer are identical. The winning foreign aid platform, for example, reflects the median belief that foreign aid is a major drag on economic performance. So the winning platform probably provides minimal foreign aid. If (as the contrasting belief distribution of economists indicates) the median belief about the effects of foreign aid is far from the truth, then the equilibrium policies are far from the optimal policies.

Political failures resulting from irrationality can be seen as a collective action problem: Everyone can be better off if the median political belief deviates less from rational expectations. The optimality of the outcome depends on the median degree of bias, but voters choose their beliefs knowing that they will not significantly change that median. The problem is not irrationality per se, but the fact that its consequences spill over onto other people; irrationality is socially costly but privately free. In contrast, if people use astrology to make career or marriage decisions, the cost of irrationality is private. The standard welfare theorems apply.

Note that in this setting log-rolling or other political bargains may actually exacerbate inefficiencies, leading to suboptimal policies even when the median belief is rational. The fundamentals underlying political deals - like all political decisions - are voters' actual beliefs given their incentive structure. Suppose that $90 \%$ of the population rationally perceives that the net benefit of foreign oranges is $\$ 10$ per person, but $10 \%$ of the electorate irrationally thinks that the net harm to them is $\$ 200$ per person. 
Individuals in both groups might support a political compromise to ban foreign oranges, tax $\$ 91$ from the irrational minority, and redistribute it to the rational majority. The members of the rational majority support it because they correctly see that they benefit by $\$ 81$. At the same time, individuals in the irrational minority individually still face a zero marginal cost of irrationality, so they have no incentive to acknowledge that their net benefit from this political deal is $-\$ 101$, not $+\$ 109$.

All collective action problems imply foregone gains to trade. Yet if voter irrationality is the problem, it will be hard to correct with ordinary log-rolling. Political trades need the majority's support given private payoffs. Since people who change their mind cannot be distinguished from those who remain irrational, "bribing" them does not change marginal incentives. Each voter has the incentive to free ride off the rationality of the electorate as a whole, implicitly figuring "The deal will pass (fail) whatever I think, so why change my mind?" Bribe or no bribe, agents are individually better off if deny that their beliefs are irrational, retain those beliefs, and vote on the basis of them. Suppose that in reality, free trade provides $\$ 500$ in benefits to each voter, but $60 \%$ are willing to pay up to $\$ 2$ for the irrational belief that free trade costs them $\$ 1000$. A simple vote for free trade will clearly fail, so someone proposes a political deal that establishes free trade and pays a $\$ 5$ bribe to each of the protectionists. The protectionists will oppose this deal as well: At the margin he gains $\$ 2$ by believing that the deal really costs him $(\$ 1000-\$ 5)=\$ 995$. Unless one individual's vote determines whether it passes, a political accord that gives him $\$ 5$ merely makes him $\$ 5$ richer without affecting the marginal private cost of irrationality. 13

\footnotetext{
${ }^{13}$ One conceivable way around this problem (albeit one inconsistent with the secret ballot) is to somehow condition payoffs on how an individual actually votes.
} 


\section{b. The Supply Side}

Competitive pressure would force standard fully rational politicians to offer the policies that irrational voters want. But if rational irrationality is an important factor in politics, how likely are politicians to actually be fully rational? And does this have any implications for political outcomes?

Politicians, just like other people, may prefer some beliefs over others. But unlike average voters, politicians often do have a significant probability of affecting outcomes, and their efforts have direct repercussions. A politician who does not have rational expectations about the impact of his policy stances on his career pays a high price, so in this area the standard arguments for rationality (Muth 1961) are compelling. Politicians who systematically misunderstand voters' feelings forego large opportunities for political profit. They have an incentive to learn from mistakes and hire expect advice. Systematic mistakes about what the voters want also open a politician to takeover bids from more rational challengers. In any case, people with rational expectations about voters' preferences self-select into the political arena. Even if this is a small fraction of the population, it could easily be large compared to the number of available offices.

Other systematic mistakes about their technology for producing votes are similarly unlikely: politicians cannot afford to have irrational expectations about the number of votes the marginal value PAC dollar buys, the probability the press will uncover skeletons in their closet, or the likelihood that evidence of current indiscretions will leak out. Rationality about expected compensation pays too: Politicians are unlikely to have irrational expectations about their level of fringe benefits, or the extent to which political experience will ultimately increase their market value in their post-political career. 
However, it does not follow that politicians will be rational about the actual impact of the policies that they implement. They merely need to gauge voters' reaction to their policies; if the voters have irrational expectations about what policies will accomplish, a politician who rationally second-guesses them gets little benefit. In fact, if it is indeed impossible to fool all of the people all of the time, politicians who share the irrational assessments of their constituents may actually be at a competitive advantage compared to rational politicians who cynically pander to the prejudices of the electorate. ${ }^{14}$ (Caplan 1999c) As Fremling and Lott (1996) observe:

The public choice problem is not necessarily dependent on asymmetric information where knowledgeable vote-maximizers deceive the voters. For example, voters could successful sort into office politicians who intrinsically value the same positions as the voters... If so, the result could be "populist" politicians who take the positions of the voters even when this may have foolish consequences. Political candidates who realize the adverse consequences of the "populist" agenda would not be elected. (p.290)

These peculiar incentives also help explain the kinds of human capital that politicians are most likely to have. The economic role of government has greatly expanded since the New Deal, but the percentage of Congressmen with professional training in economics remains negligible. (Amer 1998) Instead, the modal politician's degree is in law; "70 percent of the presidents, vice presidents, and cabinet officers of the United States and more than 50 percent of the U.S. senators and House members" have been lawyers. (Dye and Zeigler 1996, p.295) Economic issues are important to voters, but they don't want politicians with economic expertise - especially not ones who will lecture them and point out their confusions. $\frac{15}{15}$ Rather, the electoral process most frequently picks out individuals who are professionally trained to gauge the emotions of an audience, to

\footnotetext{
${ }^{14}$ Or as Groucho Marx remarked, "The secret of life is honesty and fair dealing. If you can fake that, you've got it made." (www.groucho-marx.com, 1999)

15 "Only a presidential candidate with limited faculties would try to explain to American voters the economic differences between a tariff and a quota." (Magee, Brock, and Young 1989, p.260)
} 
weigh how it will react to different kinds of rhetoric, and to plead a case as persuasively and sincerely - as possible regardless of its merits. ${ }^{16}$ (Boudreaux and Lee 1997) The people who make economic policy do not know much economics (Stiglitz 1998), but they do know how to figure out the most engaging way to tell people what they want to hear. Indeed, as Fremling and Lott hint, more knowledge about economics could be a dangerous thing for a politician, making it harder to sincerely embrace the most popular positions.

In itself, the irrationality of voters provides politicians with no additional "slack" or opportunity for shirking. However, certain kinds of irrational beliefs could easily have this effect: Specifically, overestimates of the reliability of another person's judgments. The Pope, for example, has wide latitude to dictate many people's opinions on faith and morals. The reason is not irrationality per se (which by itself would still constrain the Pope to say what people want to hear in order to retain members), but rather that many people believe that the Pope's rulings on these matters are infallible. Fanatical followers in totalitarian movements often provide their leaders with comparably loose constraints. "The Duce is always right," (Gregor 1969, p.120) went a popular Fascist slogan; or as Rudolf Hess declared in 1934:

With pride we see that one man remains beyond all criticism, that is the Führer. This is because everyone feels and knows: he is always right, and he will always be right. The National Socialism of all of us is anchored in uncritical loyalty, in the surrender to the Führer that does not ask for the why in individual cases, in the silent execution of his orders. We believe that the Führer is obeying a higher call to fashion German history. There can be no criticism of this belief. (History Place, 1996)

In democracies, charismatic political leaders - or more mediocre personalities wearing

${ }^{16}$ The main difference between legal pleading and political pleading is that a lawyer can get rich by defending unpopular clients, but few politicians can succeed by standing up for unpopular causes. 
the mantle of traditional authority - could enjoy the same sort of slack on a smaller scale. This helps explain why frequently opinion polls show opposition to policies before they pass, but support after the government approves them. If no new information about the efficacy of the new policies has arrived, then what the electorate must find convincing is the very fact that they were mandated by leaders and institutions they put their faith in. Such faith gives politicians the "wiggle room" for ideological (or other) shirking for which most competitive political models cannot account. (Bender and Lott 1996; Bernstein 1989) Consider the case of Nafta. As section 2 b's discussion of populism would make one expect, a large majority was against Nafta from the outset. Resistance diminished in the face of Clinton's campaign for passage. (Tonelson 1997) Still, about two weeks prior to passage, a majority continued to oppose it, with $46 \%$ for and $38 \%$ against. (Los Angeles Times 1993a) Both houses of Congress approved it anyway. About two weeks after approval, public opinion had reversed, with $41 \%$ for and $27 \%$ against. (Los Angeles Times 1993b) Though the public gradually reverted to its protectionist priors, majority support for Nafta persisted for over a year, with no apparent long-run damage to Clinton's popularity. (Tonelson 1997)

Similarly, there is nothing about irrationality in general that implies that uninformative or misleading political advertising works - especially when funded by self-serving interest groups. 1.7 But specific kinds of deviations from rational updating will have these effects. Voters may be willing to condition their beliefs on emotionally compelling, logically irrelevant signals; hence, the prominence political ads give to rivals' sexual improprieties

\footnotetext{
${ }^{17}$ Gary Becker is surprisingly sympathetic to this view: "...I believe that voter preferences are frequently not a crucial independent force in political behavior. These 'preferences' can be manipulated and created through the information and misinformation provided by interested pressure groups, who raise their political influence partly by changing the revealed 'preferences' of enough voters and politicians. (Becker 1983, p.392)
} 
and other personal scandals. Or voters may over-weight signals that do have some logical relation to the facts; hence, the politicians' heavy reliance on startling anecdotes like the Willie Horton story rather than aggregate crime statistics. (Olson 1982, p.26-27; Popkin 1991; Tversky and Kahneman 1982) Or voters may disregard information too boring or unpleasant to think about; hence, the conspicuous absence of seemingly winwin feats of political entrepreneurship like one-time cash buyouts of inefficient special interests. Depending upon the rationality of voters' updating procedures, more "informed" opinion may not be an improvement over full ignorance.

The supply-side forces tend to amplify the equilibrium impact of such irrational updating. The media want to entertain citizens; politicians, to influence their votes. If informing voters achieves these ends, the media and politicians have an incentive to distribute free information. (Wittman 1995, 1989; Popkin 1991) But this may be "information" only in a loose sense of the word. (Schumpeter 1976) If voters overreact to anecdotal evidence, for example, this gives the media and politicians incentives to deliver more anecdotes. Conversely, if audiences tend to ignore economic analysis of policy, little economic analysis will be supplied. Neither the media nor politicians are likely, for example, to pay attention if academics mail them reprints of academic articles exposing abstruse government failures, as Wittman $(1995$, p.99) recommends. The way for the journalists to get viewers and readers, and for politicians to get votes, is not to provide objective information, but to tell people what they want to hear. If the audience does not care, neither will information providers.

\section{Conclusion}

Political failure models with fully rational agents promise more than they can deliver, explicitly denying the existence of irrationality while covertly assuming it. (Wittman 1995, 
1989; Breton and Wintrobe 1982, Wintrobe 1987, Coate and Morris 1995) Appealing to "poorly designed institutions" (Holcombe 1985, p.4) rather than voter irrationality makes it difficult to understand why rational voters approved poorly designed institutions in the first place. Even with dysfunctional institutions, fully rational voters have an array of strategies to cheaply advance their interests. Consider for example Crew and Twight's (1990) account of political failure: "[l]t is not simply a matter of the public's being fooled or tricked. It is at root a story about rational political inaction by individual taxpayers in the face of changing transaction-cost constraints." (p.24) But with rational voters, this effort to expand the scope of government would backfire: Deliberately raising transaction costs signals programs of poor quality, reducing voters' willingness to pay for them. Amplifying their information costs would be equally futile: The rational response to asymmetric information is to buy less, not more. (Breton and Wintrobe 1982) Rational voters could in effect say "If the benefits of the program are not obvious, I'm against it." Facing such scrutiny, programs' promoters would want to make their case transparent to prove they have nothing to hide.

"Governments do pursue inefficient policies. But are these due to voter and politician irrationality or are they systematically related to the constraints of the system as the rational model would predict?" (Coursey and Roberts 1991, p.87) I maintain that this is a false alternative: Voter and politician irrationality arises from the constraints of the system as the rational model predicts. When irrational bias is privately costless, people consume more irrational bias. When politicians compete for the favor of voters with irrational biases, the winner tends to share those biases. Just as the logic of collective action shows that agents may rationally choose to pollute even though their collective pollution makes them worse off, the logic of collective belief shows that agents may rationally choose irrational political views even though their collective irrationality makes 
them worse off. The inordinate influence of irrationality in politics is not an anomaly for economists to explain away. It is precisely what an economic theory of irrationality predicts.

\section{References}

Akerlof, George. 1989. The Economics of Illusion. Economics and Politics, vol. 1(1): 115.

Akerlof, George, and William Dickens. 1982. The Economic Consequences of Cognitive Dissonance. American Economic Review, vol. 72(3): 307-19.

Amer, Mildred. 1998. "Membership of the $105^{\text {th }}$ Congress: A Profile." Government Division. Order No. 97-37 GOV, July 17.

Austen-Smith, David. 1991. Rational Consumers and Irrational Voters: A Review Essay on Black Hole Tariffs and Endogenous Policy Theory. Economics \& Politics, vol. 3(1): 73-92.

Becker, Gary. 1983. A Theory of Competition Among Pressure Groups for Political Influence. Quarterly Journal of Economics, vol. 98(3): 371-400.

Becker, Gary. 1976. Toward a More General Theory of Regulation: Comment. Journal of Law and Economics, vol. 19(2): 248-48.

Becker, Gary. 1968. Crime and Punishment: An Economic Approach. Journal of Political Economy, vol. 76(2): 169-217.

Becker, Gary. 1958. Competition and Democracy. Journal of Law and Economics, vol. 1(1): 105-9.

Bender, Bruce, and John Lott. 1996. Legislator Voting and Shirking: A Critical Review of the Literature. Public Choice, vol. 87(1-2): 67-100.

Bernstein, Robert. 1989. Elections, Representation, and Congressional Voting Behavior: The Myth of Constituency Control. Eaglewood Cliffs, NJ: Prentice Hall.

Boudreaux, Donald, and Dwight Lee. 1997. Politics as the Art of Confined Compromise. Cato Journal, vol. 16(3): 365-81.

Boudreaux, Donald. 1996. Was Your High School Civics Teacher Right After All? Donald Wittman's The Myth of Democratic Failure. Independent Review, vol.1(1): 11128.

Brennan, Geoffrey, and Loren Lomasky. 1993. Democracy and Decision: The Pure Theory of Electoral Preference. Cambridge: Cambridge University Press.

Brennan, Geoffrey, and Loren Lomasky. 1989. Large Numbers, Small Costs: The 
Uneasy Foundations of Democratic Rule. In Brennan, Geoffrey, and Loren Lomasky, eds. Politics and Process: New Essays in Democratic Thought. Cambridge: Cambridge University Press, pp. 42-59.

Breton, Albert, and Ronald Wintrobe. 1982. The Logic of Bureaucratic Conduct: An Economic Analysis of Competition, Exchange, and Efficiency in Private and Public Organizations. New York: Cambridge University Press.

Camerer, Colin. 1987. Do Biases in Probability Judgment Matter in Markets? Experimental Evidence. American Economic Review, vol. 77(5): 981-997.

Caplan, Bryan. 1999a. Rational Ignorance vs. Rational Irrationality. Unpub. ms. Submitted to Economic Inquiry.

Caplan, Bryan. 1999b. Rational Irrationality: A Framework for the NeoclassicalBehavioral Debate. Unpub. ms.

Caplan, Bryan. 1999c. When to Fake It. Unpub. ms.

Caruth, Gorton, and Eugene Ehrlich, eds. 1988. The Harper Book of American Quotations. New York: Harper and Row.

Coate, Stephen, and Stephen Morris. 1995. On the Form of Transfers to Special Interests. Journal of Political Economy, vol. 103(6): 1210-35.

Coursey, Don, and Russell Roberts. 1991. Competition in Political and Economic Markets. Public Choice, vol. 70(1): 83-88.

Crew, Michael, and Charlotte Twight. 1990. On the Efficiency of Law: A Public Choice Perspective. Public Choice, vol. 66(1): 15-36.

Cyert, Richard, and Morris DeGroot. 1974. Rational Expectations and Bayesian Analysis. Journal of Political Economy, 82(3): 521-36.

Downs, Anthony. 1957. An Economic Theory of Democracy. New York: Harper.

Dye, Thomas, and L. Harmon Zeigler. 1996. The Irony of Democracy. New York: Wadsworth Publishing Company.

Fremling, Gertrud, and John Lott. 1996. The Bias Towards Zero in Aggregate Perceptions: An Explanation Based on Rationally Calculating Individuals. Economic Inquiry, vol. 34(2): 276-95.

Fremling, Gertrud, and John Lott. 1989. Time Dependent Information Costs, Price Controls, and Successive Government Intervention. Journal of Law, Economics and Organization, vol. 5(2): 293-306.

Frey, Bruno, and Reiner Eichenberger. 1991. Anomalies in Political Economy. Public Choice, vol.68(1-3): 71-89.

General Social Survey. 1996. URL http://www.icpsr.umich.edu/GSS/home.htm 
Gregor, A. James. 1969. The Ideology of Fascism. New York: Free Press.

Haltiwanger, John, and Michael Waldman. 1989. Rational Expectations in the Aggregate. Economic Inquiry, vol. 27(4): 619-36.

History Place. "Rudolf Hess." 1996. URL

http://www.historyplace.com/worldwar2/biographies/hess/

Holcombe, Randall. 1985. An Economic Analysis of Democracy. Carbondale: Southern Illinois University Press.

Kuran, Timur. 1995. Private Truths, Public Lies: The Social Consequences of Preference Falsification. Cambridge: Harvard University Press, 1995.

Los Angeles Times. 1993a. "Gallup Poll Finds 46\% Opposed, 38\% in Favor of NAFTA." Section: Part A; Page: A-14, November 9.

Los Angeles Times. 1993b. "The Times Poll: Economy and President Seen More Favorably," Los Angeles Times. Section: Part A; Page: A-1, December 9.

Lott, John. 1997a. Does Political Reform Increase Wealth?: Or, Why the Difference Between the Chicago and Virginia Schools is Really an Elasticity Question. Public Choice, vol. 91(3-4): 219-27.

Lott, John. 1997b. Donald Wittman's The Myth of Democratic Failure. Public Choice, vol.92(1-2): 1-13.

Magee, Stephen, William Brock, and Leslie Young. 1989. Black Hole Tariffs and Endogenous Policy Theory: Political Economy in General Equilibrium. Cambridge: Cambridge University Press.

Muth, John. 1961. Rational Expectations and the Theory of Price Movements. Econometrica, vol. 29(3): 315-35.

National Survey of Public Knowledge of Welfare Reform and the Federal Budget. 1995. Kaiser Family Foundation and Harvard University, January 12, \#1001.

Olson, Mancur. 1982. The Rise and Decline of Nations: Economic Growth, Stagflation and Social Rigidities. New Haven: Yale University Press.

Olson, Mancur. 1965. The Logic of Collective Action: Public Goods and the Theory of Groups. Cambridge: Harvard University Press.

Pesaran, M. Hashem. 1987. The Limits to Rational Expectations. Oxford: Blackwell.

Popkin, Samuel. 1991. The Reasoning Voter: Communication and Persuasion in Presidential Campaigns. Chicago: University of Chicago Press.

Rowley, Charles. 1997. Donald Wittman's The Myth of Democratic Failure. Public Choice, vol.92(1-2): 15-26. 
Saad, Lydia. 1996. "Issues Referendum Reveals Populist Leanings." The Gallup Poll Monthly, No. 368, pp.2-6.

Sheffrin, Steven. 1996. Rational Expectations. Cambridge: Cambridge University Press.

Schumpeter, Joseph. 1976. Capitalism, Socialism, and Democracy. New York: Harper.

Stigler, George. 1986. Economics or Ethics? In The Essence of Stigler, edited by K. Leube, and T. G. Moore. Stanford: Hoover Institution Press, pp.303-336.

Stiglitz, Joseph. 1998. Distinguished Lecture on Economics in Government: The Private Uses of Public Interests: Incentives and Institutions. Journal of Economic Perspectives, vol. 12(2): 3:22.

Survey of Americans and Economists on the Economy. 1996. The Washington Post, Kaiser Family Foundation and Harvard University, October 16, \#1199

Tonelson, Alan. 1997. "Free Trade is Not Just Bad Policy, but Bad Politics." Detroit News, May 22. URL http://detnews.com/EDITPAGE/9705/22/column/column.htm.

Tversky, Amos, and Daniel Kahneman. 1982. Availability: A Heuristic for Judging Frequency and Probability. In Kahneman, Daniel, Paul Slovic, and Amos Tversky, eds. Judgment Under Uncertainty: Heuristics and Biases (Cambridge: Cambridge University Press), pp.163-178.

Wintrobe, Ronald. 1987. The Market for Corporate Control and the Market for Political Conduct. Journal of Law, Economics, and Organization, vol. 3(2): 435-48.

Wittman, Donald. 1995. The Myth of Democratic Failure: Why Political Institutions are Efficient. Chicago: University of Chicago Press.

Wittman, Donald. 1989. Why Democracies Produce Efficient Results. Journal of Political Economy, vol. 97(6): 1395-1424.

www.groucho-marx.com. 1999. "Groucho Marx is Here." URL http://www.grouchomarx.com. 


\section{Diagram 1: Incentives and Estimation}

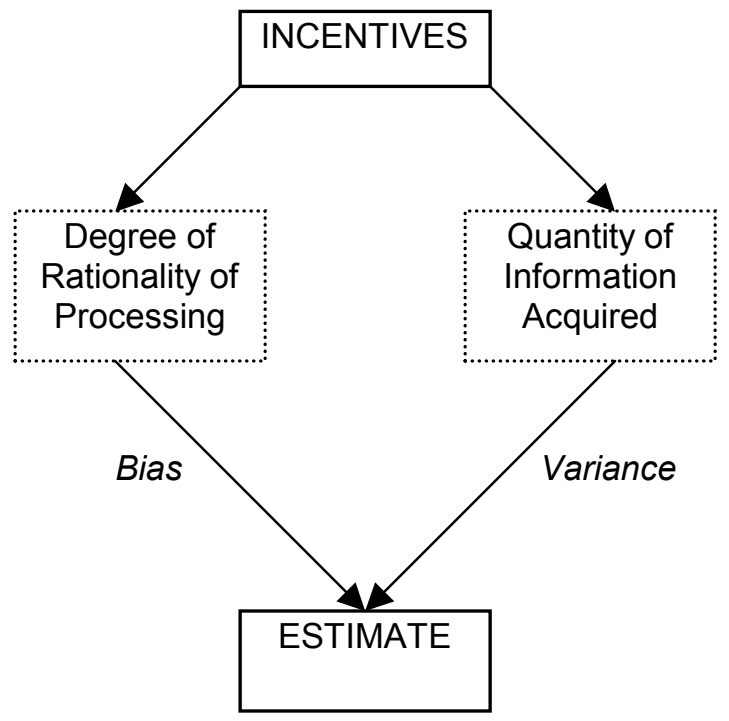

Diagram 2: The Demand for Irrationality

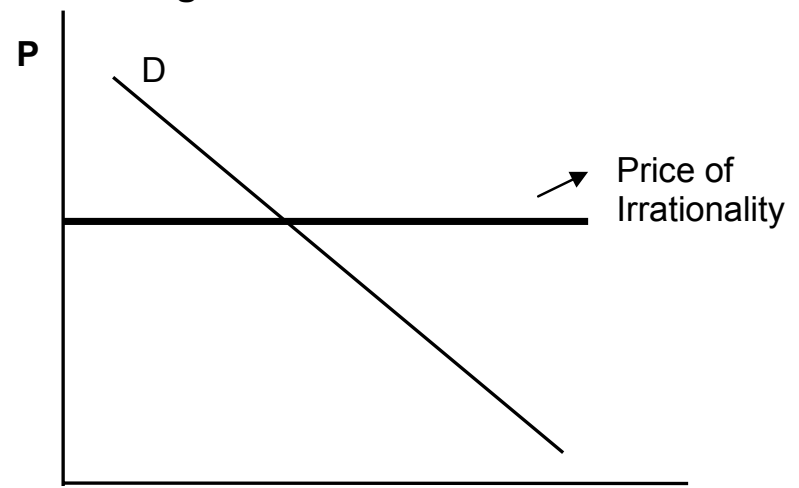

Quantity of Irrationality

Diagram 3: Neoclassical vs. "Near-Neoclassical" Demand for Irrationality

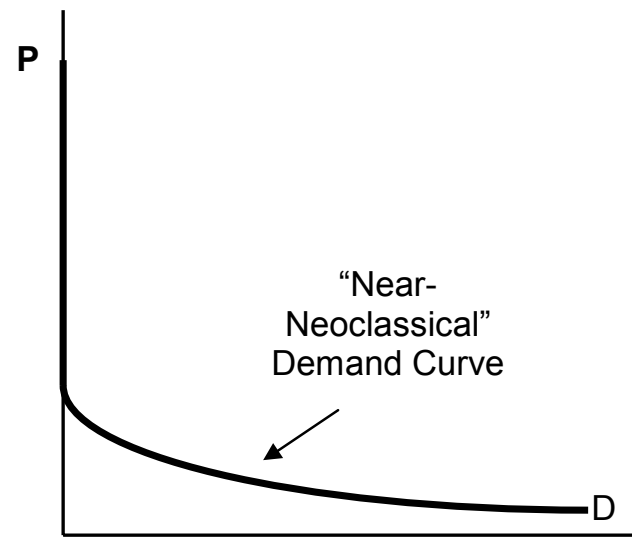

Quantity of Irrationality

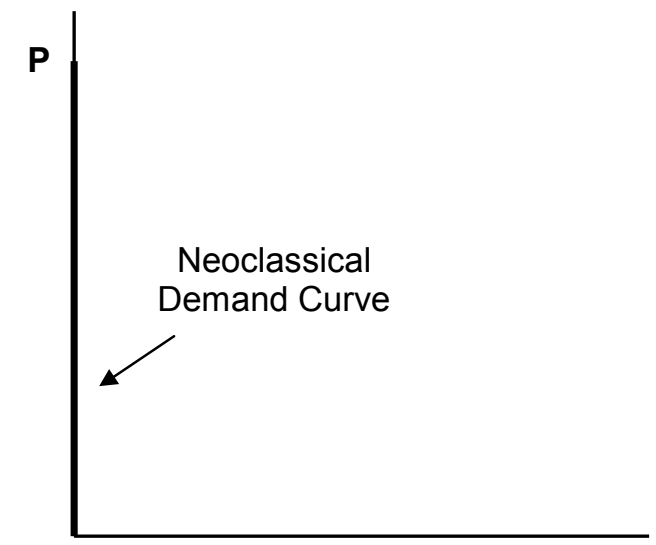

Quantity of Irrationality 


\section{Diagram 4: Price-Sensitivity of the Demand for Irrationality}

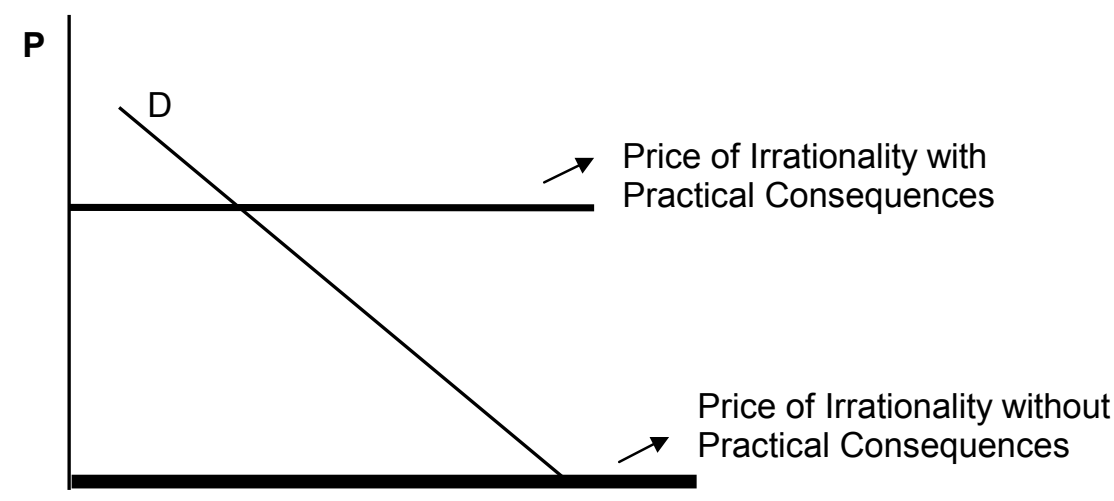

Quantity of Irrationality

\section{Diagram 5: Electoral Impact of Irrationality with Identical Voters}

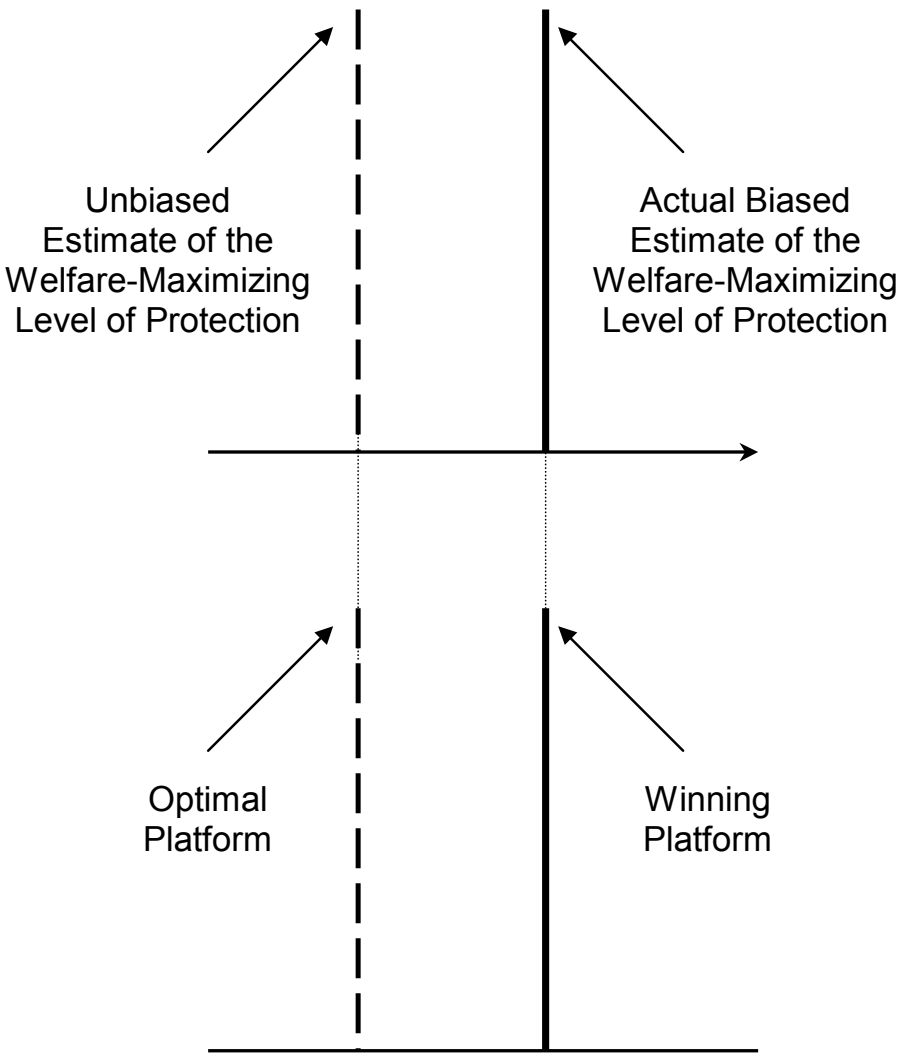

Top: Distribution of Beliefs on Welfare-Maximizing Level of Protection Bottom: Distribution of Most-Preferred Platforms on Protection 
Diagram 6: Electoral Impact of Irrationality of Otherwise Identical Voters with Heterogeneous Beliefs

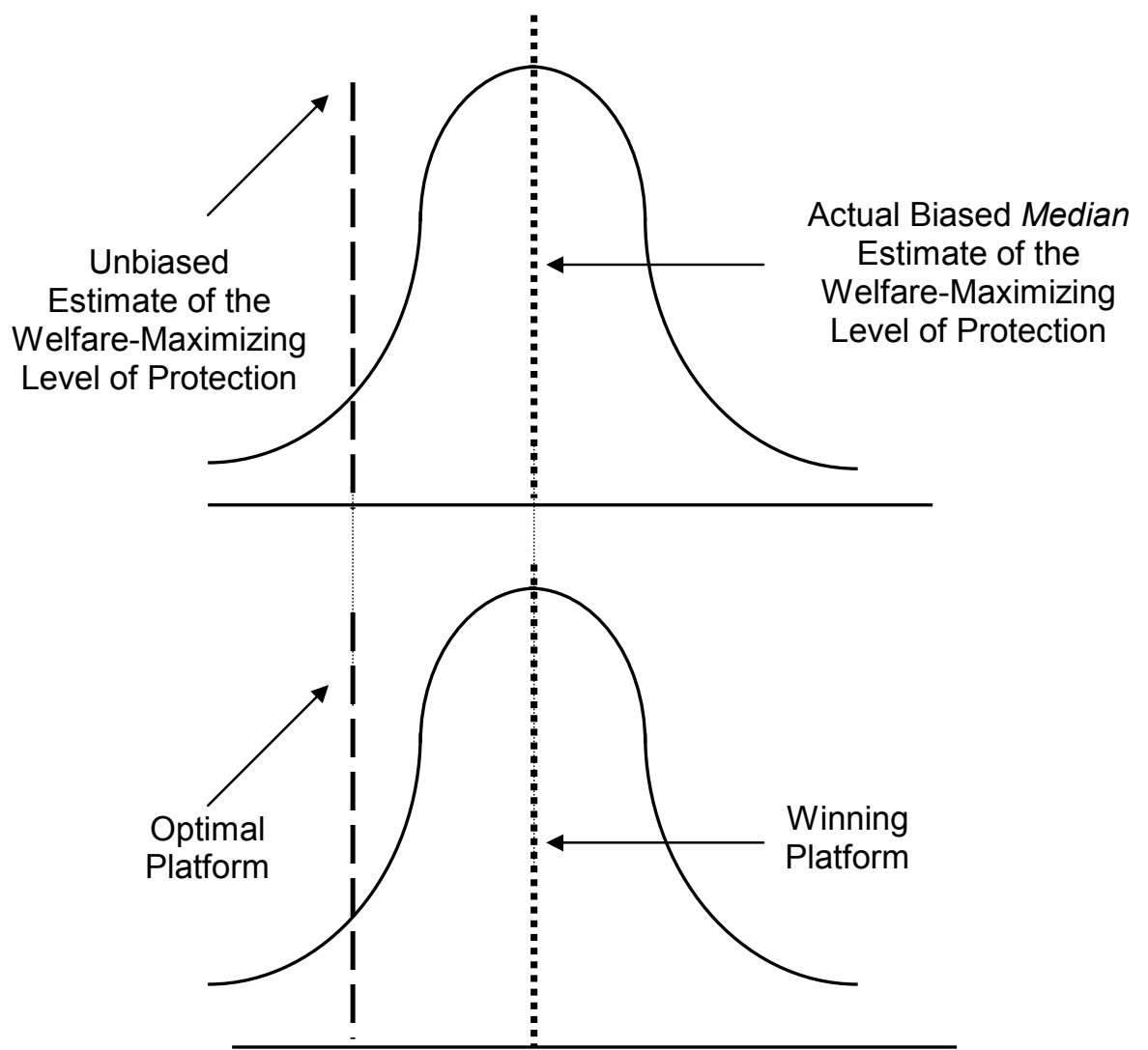

Top: Distribution of Beliefs on Welfare-Maximizing Level of Protection Bottom: Most-Preferred Degree of Protectionism 